\title{
Climate change and the economic consequences of Brexit
}

\section{Revised version: 3 Jan 2017}

\author{
Cameron Hepburn and Alexander Teytelboym
}

Institute for New Economic Thinking, University of Oxford

\section{Introduction}

Climate change did not play a prominent role in the Brexit referendum campaign, but following the surprising vote to leave there has been a scramble among academics and policy makers to understand exactly what the exit from the EU will mean for climate policy. This short paper examines the implications of the referendum and, eventually, of Brexit for the economics of climate change in the UK, the EU and beyond. The three main potential impacts from Brexit with respect to climate change are:

1. Changes to British climate policy, especially the carbon price faced by firms and households, as well as reduction of support for research and development in clean energy technologies in Britain;

2. Changes to the EU's climate and clean innovation policy;

3. Changes to the likelihood that nations collectively reach rational international agreements to reduce emissions, partly affected by underlying shifts in the perceived value of expertise.

On the first area, an optimistic view is that Brexit is an opportunity for Britain to unilaterally improve upon the existing EU climate policies as they apply to the UK. A more pessimistic view is that EU climate policies already left plenty of room for member states to pursue more ambitious climate agendas; the British Climate Change Act (2008) is one example. By revealed preference, therefore, it is unlikely that ambitious policies would be put in place now if they were not before. Rather, if EU climate policies are removed, action on climate change in Britain is more likely to be weaker rather than stronger. The exception, perhaps, might be carbon pricing.

On the second area, an even more optimistic view is that the EU might use Brexit as an opportunity to improve upon its EU-wide climate policies. However, it seems very unlikely that Brexit will trigger an increase in ambition or economic rationality by the remaining EU member states, given that Britain has been a strong advocate and pioneer of climate policies at the EU level. The likely outcome is the opposite: EU's own ambitions are likely to lower as a result of Brexit.

The third area is much harder to pin down. Any sensible response to climate change relies on expertise across dozens of areas of physical and social sciences. This is exemplified by composition and work of the Intergovernmental Panel on Climate Change. The public derision of 'experts' during the referendum campaign (see, for example, Mance (2016)) undermines the value of the knowledge necessary to support economically rational action. The same populist themes heard in the EU referendum resonated in the November 2016 US presidential election and December 2016 Italian constitutional referendum. These populistic undercurrents, related to the Brexit vote, do not portend good news for ambitious climate policy.

The paper is structured around these three themes, in decreasing specificity but increasing significance, as follows. In Section 2, we review the shifts in UK climate policy that can already be observed following the referendum, and provide some indications of potential future pathways. Given UK emissions are approximately $1 \%$ of the global total (European Commission, 2016), the overall 
global economic consequences of changes to UK climate policy are unlikely to be large. Local impacts on the UK economy are ambiguous and highly dependent on the response of the British government. In section 3, we consider the impacts of likely Brexit on EU climate policy. The UK has been a driving force behind more ambitious policy in Europe. Weaker EU climate policy will have greater global significance than weaker UK climate policy, given that EU emissions are eight times larger than UK emissions. In section 4 we consider the wider impacts of a reduction in the perceived value of facts and expertise. Section 5 concludes that the impact of Brexit on climate policy is likely to be negative for the ambitiousness of action and for its economic efficiency. It is therefore concluded that the economic consequences are also negative.

\section{Impact on UK climate change policy}

The impact of Brexit on domestic climate policy might at first glance seem to be rather limited. Britain has been leading on climate change, including by setting legally-binding targets under the Climate Change Act that are more ambitious that those of the EU, maintaining a higher carbon price than the EU ETS, and in being the first major economy to pledge to phase out coal-fired power stations by 2025. ${ }^{1}$ The United Kingdom is already a member of the Mission Innovation pledge to double spending on clean energy research and development in its own capacity.

However, as set out below, closer analysis shows that much of the reduction in emissions over the coming decades would flow from EU policies that will now need to be replicated or replaced. New arrangements on carbon pricing will be required. While this presents the opportunity for more efficient or more ambitious climate policy, it is unclear whether the political appetite for this is particularly strong.

While the former Prime Minister David Cameron pledged to run the 'greenest government ever' (Randerson, 2010), the position of the current Prime Minister, Theresa May, is not completely clear. Her former Chief of Staff, Nick Timothy, recently described the Climate Change Act as a "unilateral and monstrous act of self-harm" (Timothy, 2016), although May herself at the time described the Act as "necessary and ambitious" (May, 2008). Her new government swiftly abolished the Department of Energy and Climate Change and absorbed it into the Department of Business, Innovation, and Skills, creating a new Department of Business, Energy, and Industrial Strategy (BEIS). While some commentators described this as a downgrading of climate change compared to the previous administration, ${ }^{2}$ it is plausible that climate change will be more integrated into energy and industrial strategy and play a key part of emission reduction across more sectors (Committee on Climate Change, 2016). For instance, Greg Clark, the Secretary of State for BEIS, announced modest additional funding for electric vans in October (BEIS, 2016) and reportedly described electric vehicles, connected autonomous vehicles and battery storage as an "emblematic area of focus" in November (Ruddick, 2016).

\footnotetext{
${ }^{1}$ Important advances in knowledge of climate science have been conducted in Britain (Allen et al., 2009; Stott et al., 2004), following the tradition established by Tyndall (1872). In 2002-2003, the UK led in trialling a carbon emissions trading scheme, which was a precursor to the EU Emissions Trading Scheme (EU ETS). The Stern Review changed the discourse on the economics of climate change (Stern et al, 2006). And the words 'climate change' first appeared in the name of a government department in the United Kingdom - the Department of Energy and Climate Change - in 2008.

2 The new department "brings together responsibilities for business, industrial strategy, science, innovation, energy, and climate change", and, notably, these areas are not listed in alphabetical order. There is a junior ministerial portfolio for "climate change and industry".
} 
Similarly, there has been only modest change to the British approach to international climate change policy. The new Foreign Secretary, Boris Johnson who led the campaign to leave the EU, ratified the Paris Agreement in November 2016. Once Britain leaves the EU, it will need to develop its own Nationally Determined Contribution (NDC) but it has a good basis for this with the Climate Change Act and the actions under the review of the independent Committee on Climate Change. Thus far, the evidence suggests that the new government has not taken a wildly different approach to climate policy than the previous administration.

Figure 1 shows that the UK's overall domestic emission reduction targets, embedded in the Climate Change Act, are already more ambitious than those emanating from the EU. For instance, while the EU is targeting emissions reductions of $40 \%$ by 2030 on 1990 levels (European Commission, 2014), the UK's domestic target in the fifth carbon budget, legislated in July 2016 (that is after the Brexit referendum), is for a reduction of 57\% (Committee on Climate Change, 2015). The UK is the only major European economy to have a legally binding climate target and to have a plan for complete coal phase out (among smaller economies, Finland and Denmark also have both).

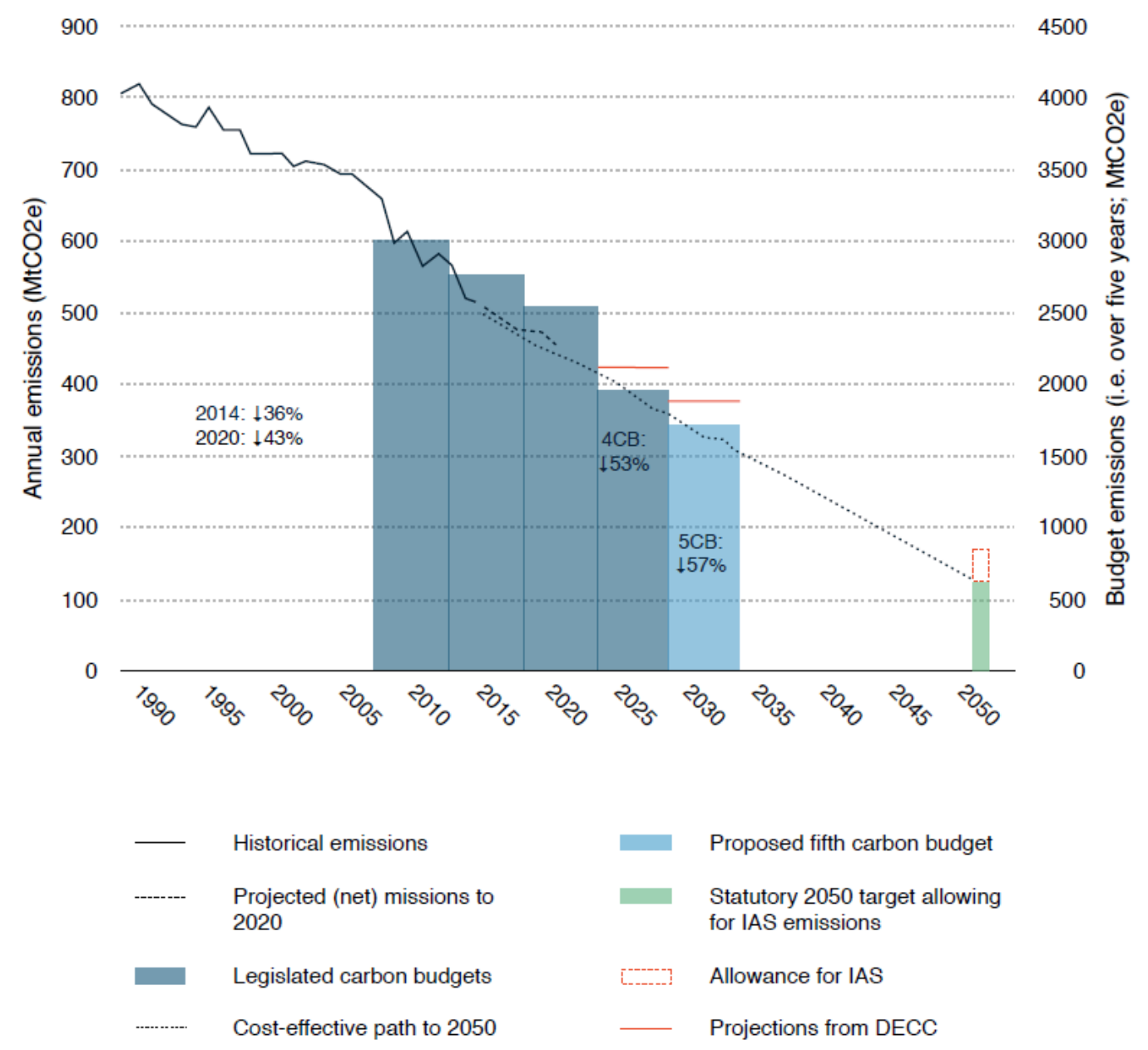

Figure 1: UK past and projected future emissions compared to the CCA carbon budgets

The reason Brexit might bite - for good or ill - is because there is a number of other EU Directives that relate to climate change that are genuinely 'additional', in the sense that they proscribe UK action that would not otherwise be taken under British policies. Some of these directives help the UK meet its own climate targets; without them, alternative policies would need to be put in place. The Climate 
Change Committee estimates that by 2030 EU policies (implemented through the EU instruments directly or through British legislation to meet EU targets) would directly contribute to over half of all emissions reduction in the UK. These are shown in Table 1, adapted from the recent analysis by the Committee on Climate Change (2016).

\begin{tabular}{|c|c|c|c|}
\hline \multirow{2}{*}{ Sector } & \multirow{2}{*}{ Key EU-level policies } & \multicolumn{2}{|c|}{$\begin{array}{l}2030 \text { UK emission savings } \\
\text { covered by EU-level policies }\end{array}$} \\
\hline & & $\mathrm{MtCO} 2 \mathrm{e}$ & $\%$ of total required \\
\hline Transport & $\begin{array}{l}\text { - New car, van \& HGV emission standards } \\
\text { - Biofuels (Renewable Energy Directive) } \\
\text { - Eco-driving Regulations } \\
\text { - Air Quality: Framework Directive \& National Emission Ceilings }\end{array}$ & 56 & $87 \%$ \\
\hline Power & $\begin{array}{l}\text { - EU Emissions Trading System (ETS) } \\
\text { - Energy Union \& single energy market } \\
\text { - Renewable Energy Directive } \\
\text { - Industrial Emissions }\end{array}$ & 18 & $23 \%$ \\
\hline Industry & $\begin{array}{l}\text { - EU Emissions Trading System (ETS) } \\
\text { - Renewable Energy Directive } \\
\text { - Energy Efficiency Directive }\end{array}$ & 14 & $82 \%$ \\
\hline F-gases & $\begin{array}{l}\text { - F-gas Regulation } \\
\text { - Nitrate and Water Framework Directives }\end{array}$ & 12 & $100 \%$ \\
\hline Buildings & $\begin{array}{l}\text { - Renewable Energy Directive } \\
\text { - Energy Efficiency Directive } \\
\text { - Product standards and labelling } \\
\text { - Directives }\end{array}$ & 11 & $50 \%$ \\
\hline Waste & $\begin{array}{l}\text { - Landfill and Waste Framework Directives } \\
\text { - Circular Economy Package }\end{array}$ & 4 & $100 \%$ \\
\hline $\begin{array}{l}\text { Land Use \& } \\
\text { Forestry }\end{array}$ & - Common Agricultural Policy (CAP) & 2 & $76 \%$ \\
\hline Agriculture & $\begin{array}{l}\text { - Common Agricultural Policy (CAP) } \\
\text { - Nitrate and Water Framework Directives }\end{array}$ & 0 & $0 \%$ \\
\hline \multicolumn{2}{|c|}{ Economy-wide } & 117 & $55 \%$ \\
\hline
\end{tabular}

\section{Table 1: Additional EU Directives}

The need to rethink these directives represents a potential opportunity for reform or, in fact, for eliminating the most economically inefficient of them. In power, the two most significant such directives are the European Emissions Trading Scheme and the European Renewables Directive. Other significant climate policies are addressed by the paper on energy (energy efficiency, smart meters, interconnection, and the Internal Energy Market) by Michael Pollitt (this issue) and their absence in agriculture is underlined by Dieter Helm (this issue). Transport, industry and buildings are also very substantial areas, but beyond the EU ETS and the renewable energy directive we do not explicitly address them here, given space limitations. 


\section{European Emissions Trading Scheme (EU ETS)}

The central pillar of EU climate policies is the EU ETS, the largest carbon emissions trading scheme in the world. Like in all EU (as well as non-EU European Economic Area) countries, many British electricity generators and industrial emitters are covered by the EU ETS. Brexit leaves the continued participation of the UK in the EU ETS uncertain. If Britain chooses to leave the EU but remain or rejoin the European Economic Area, then, like Norway, it will participate in the EU ETS. But if Britain continues to participate in the EU ETS in any capacity other than as a full member of the EU, it is likely to lose much of the influence it currently has in shaping the trading scheme.

With carbon permit prices hovering in the single digits, the EU ETS undoubtedly needs urgent reform (Hepburn and Teytelboym, forthcoming). However, European politics prevent wholesale reorganisation, such as expanding sectoral coverage or introducing price collars and full auctioning of permits. Instead the EU has proceeded to fix the EU ETS by ineffective compromises, such as backloading permits and the Market Stability Reserve (Hepburn et al., 2016).

Were Britain to leave the EU ETS, a new carbon price would be needed to meet the self-imposed carbon budget. Options could include returning to the UK-wide emission trading scheme (which could - by fixing the quantity of emissions at the appropriate level - guarantee hitting the carbon reduction target in the Climate Change Act) or replacing it entirely with a carbon tax. This would not have dramatic economic consequences given that Britain already has a minimum price for carbon, implemented by the Carbon Price Support and the Carbon Price Floor. Indeed, if Britain leaves the EU ETS, it could simply transition the Carbon Price Floor into a carbon tax. The economic impact, including on polluters, would depend on the level of the tax. As Hepburn, Pless and Teytelboym (2016) argue, recently decisions to freeze the Carbon Price Support have meant that the Carbon Price Floor is substantially below the social cost of carbon, and indeed below the nationally self-interested level of around $\$ 40$ or $£ 30$ (Parry, Veung and Heine, 2015). Increasing the carbon price to at least the selfinterested level would improve welfare as a result of co-benefits such as the reduction in local air pollution.

\section{European Renewable Energy Directive and other climate-related directives}

The EU has a renewable energy target of $20 \%$ by 2020 . As part of this, Britain has an overall national target of $15 \%$ with sub-targets of $30 \%$ for renewable electricity, $12 \%$ renewable heat, and $10 \%$ renewable transport (House of Commons Energy and Climate Change Committee, 2016, p. 44, footnote 313 ). The European target for 2030 is $27 \%$ renewables, but there will be no binding targets on any member state (though the European Commission has proposed enforcement mechanisms).

At the conclusion of the Brexit negotiations, whether in 2019 or later (see Catherine Barnard in this issue), Britain will not have any legislated renewable energy targets. This may well be a good thing. The EU imposes renewable energy targets in part because EU carbon pricing is inadequate to deliver the necessary energy transformation, but the renewable energy targets themselves further undermine the EU ETS. Membership of the EU has implied that Britain has had to implement additional, overlapping and inefficient policies in order to reach its share of the renewable energy targets. Once outside the EU, the only target that will matter for British climate policy is the emission reduction target set by the Climate Change Act. This target can be more efficiently achieved with appropriate carbon pricing (via emission trading or a carbon tax), support for clean energy technologies (as we discuss below), and other ancillary policies (Fankhauser et al., 2010).

Like the European Renewable Energy Directive, many other European directives relating to climate change, such as the Energy Efficiency Directive, Energy Labelling Framework Directive and Eco-design 
Framework Directive and Energy Performance of Buildings Directive, will likely be incorporated into British law in the so-called "Great Repeal Bill" (House of Commons Library, 2016). The process of unpicking or adapting these directives for the UK context will take years therefore non-adherence to new EU climate change directives is unlikely to have immediate economic consequences.

\section{Support for R\&D in clean technologies}

Potentially, the most significant long-term impact of Brexit on the British green economy is the loss of access to EU clean energy innovation funds. Britain is a world-leader in tertiary education, science and engineering, specifically in research and development of new low-carbon technologies. This is in no small part due to the fact that Britain receives a disproportionately large share of EU research funding through the LIFE+ fund, Horizon 2020 and the NER300 mechanisms (House of Commons Energy and Climate Change Committee, 2016). Moreover, following Brexit, Britain is likely to lose access to EU Structural and Regional Funds (€1.6 billion in support low-carbon projects 2014-20) as well as more specific programmes, such as the European Energy Programme for Recovery (over $€ 400$ million in funding since 2009). May's government has vaguely "guaranteed" any EU grants that could be lost because of Brexit (FTI Consulting, 2016), but it has said nothing about the longer-term support for clean R\&D. But not only does R\&D matter, deployment does too. Since 2000, British low-carbon innovators have benefited from over $€ 37 \mathrm{bn}$ in funding from the European Investment Bank (Committee on Climate Change, 2016) and Brexit is creating huge uncertainty for low-carbon investors (Johnston, 2016).

During the COP21 climate negotiations in Paris in December 2015, the international community recognised the immense gap between current and necessary levels of public and private funding for low-carbon innovation. At this meeting, Britain joined other major countries in the Mission Innovation programme, which will double spending on clean energy R\&D over the coming 5 years. Most rigorous climate modelling shows that substantial increases in innovation funding is needed today and because innovation is cumulative delaying support today will be extremely costly in the future (e.g. Acemoglu et al. 2012). In that sense, a hiatus of just a few years created by uncertainty and a fall of funding for clean R\&D will amplify to a decades-long innovation gap in the future making the British economy uncompetitive. Clean energy R\&D produces huge spillovers compared to dirty technologies (Dechezlepretre et al. 2013) and public good nature of innovation requires government support to ensure a socially optimal amount of innovation is achieved.

\section{Impact on EU climate policy}

The greenhouse gas emissions of the EU are approximately eight times larger than the emissions in the UK (Eurostat, 2016). The impact of Brexit on the EU is, therefore, potentially of greater significance to climate change than the impact of Brexit on the UK. On 30 November 2016, the European Commission proposed a large package of reforms called Clean Energy for All Europeans. The package aims at delivering a EU-wide goal of $40 \%$ emission reduction by 2030 and covers the electricity market regulation and governance, energy efficiency, renewables, innovation and transport (see Michael Pollitt's article in this issue and the discussion above). It is yet unclear whether the package will become part of UK law before Britain leaves the EU.

Given the impact of the UK on EU climate policy to date, three broad trends that are plausible.

First, EU climate policy may become weaker. The UK has been an important supporter of strong climate policies. UK emission reduction targets are more ambitious than the EU-wide targets, and that the UK has a correspondingly higher (and unilateral) carbon floor price. This has given the UK a credible platform from which to persuade other European nations to reduce emissions. While 
Germany and France have also been strong supporters of climate change policy, without the UK weaker rather than stronger EU climate policies seems likely (Froggatt, Raines and Tomlinson, 2016).

Second, EU climate policy may become more dirigiste and focused on arbitrary targets. While European carbon pricing has had its problems, it is likely to be economically more efficient than a raft of interventionist policies that "pick winners" and are more likely to be subject to rent seeking. The UK has been a strong proponent of economically efficient interventions, such as carbon pricing. For instance, the UK ETS, introduced in 2002, provided early experience that was valuable for the initial design of the EU ETS. With less efficient policies, at higher costs, the political appetite for ambitious action on climate change may eventually fall.

Third, Brexit may reduce the EU's diplomatic soft power on climate. Not only has the UK been a proponent of ambitious climate targets based on carbon pricing, it has deployed the Foreign and Commonwealth Office to make this case internationally. While the USA and China made the serious pledges in the run up to the 2015 climate negotiations, it is not surprising that result was the "Paris Agreement" rather than the "Peking Agreement". The EU is a significant global emitter, and Brexit could reduce the EU's ability to collectively negotiate such agreements in future. Outside the EU, the UK could become a "middle power", such as Canada or South Korea, on climate.

\section{Wider impacts}

There are two subtler, more ambiguous, and yet potentially more important trends associated with Brexit. It is far from obvious how events will develop in these two areas, but given their significance we offer some brief reflections here.

First, the British may "have had enough of experts" (Mance, 2016). So too, perhaps, have the Americans and the Italians, given the result of the November US presidential elections and the December Italian referendum. It is said that we are moving into a 'post-truth' society, where one person's opinion is as valid as another irrespective of the evidence (Davies, 2016). If so, this creates serious challenges for addressing any intergenerational and international challenge such as climate change that voters cannot immediately see, touch or indeed experience directly in any tangible way.

Polls showed a consistent correlation between those voting to leave the EU and climate change scepticism (Vaughan, 2016) and many leading Brexiteers are climate change sceptics (The Economist, 2016). Donald Trump, the President-elect of the United States, said that "global warming was created by and for the Chinese in order to make U.S. manufacturing non-competitive" (Wong, 2016). The same populist themes behind Brexit and the election of Trump could potentially be harnessed to undermine the science of climate change and climate policy. As the short-term costs of reducing emissions increases - as is likely to occur - the need for honest and balanced communication with voters about the economics of climate change will be as important as ever (Helm, 2015).

Second, Brexit is argued to create risks for British "soft" power around the world (MacDonald, 2016). As a leading nation of the world's largest economic area, Britain has still had considerable economic and diplomatic clout. This has been leveraged by the Foreign and Commonwealth Office to help other countries understand their shared (self)-interest in addressing climate change. British scientists and economists have been on numerous missions around the world sharing knowledge and experience, and the UK's Climate Change Act and the Committee on Climate Change has been a model that other countries, from France to the Philippines, have followed. If Britain positions itself as merely a small contributor to the climate change problem (rather than part of one of the largest emitting economic zone) and therefore plays a trivial role in the solution, it would not be completely surprising if the 
Climate Change Act were eventually repealed. This would be a major step back both for Britain and for international climate change negotiations.

\section{Conclusion}

Brexit presents both challenges and opportunities for reform of the climate change policy landscape in the UK, and the economic consequences are not a priori clear. For instance, if the dire forecasts of Brexit's direct impact on the UK economy turn out to be correct, then Brexit will likely lower emissions in the short to medium term as a consequence of reduced economic activity. That would not necessarily be good news for climate change in the long run. Stronger, more confident, more innovative, and more dynamic economies are in much better positions - especially with the voters to cut emissions in the long term.

As far as British climate policy is concerned, the government has the option of keeping most of EU legislation relating to climate policy - even potentially staying in or linking to the EU ETS. But some EU climate policies will need to be replicated or replaced if the UK is to hit its climate targets post Brexit. And uncertainty over funding for low-carbon innovation is a concern. As Mealy and Teytelboym (2016) point out in their analysis of global green exports, Britain has the capabilities to produce some of the most sophisticated green technology in the world, but this position can easily be jeopardised by an absence of a funding, certainty, and clear strategic vision.

As far as European climate policy is concerned, the loss of the UK represents the loss of a leading advocate for ambitious and economically rational climate action. At the global level, our view is that the undercurrents revealed by the Brexit vote, among other political events of 2016, could well prove very dangerous for action on climate change.

Over the next few years, as trade and migration will dominate the public discourse, climate change is unlikely to be a big political issue for the British public. Once Brexit is a fait accompli, it is possible to imagine climate change returning higher up the political agenda. At this point, the government should reiterate to the voters the economic case for pursuing the ambitions of the Climate Change Act. It is simply too early to tell whether or not in post-Brexit Britain voters will accept a case for strong climate change action. 


\section{References}

Acemoglu, D., Aghion, P., Bursztyn, L. and Hemous, D. (2012), The Environment and Directed Technical Change, American Economic Review, 102(1), pp. 131-166.

Allen, M. R., Frame, D. J., Huntingford, C., Jones, C. D., Lowe, J. A., Meinshausen, M., \& Meinshausen, N. (2009), Warming caused by cumulative carbon emissions towards the trillionth tonne. Nature, 458(7242), pp. 1163-1166.

Baxter (2014), Richard Tol Dons Cloak of Climate Denial, Desmog, 14 July 2014, Available online: https://www.desmogblog.com/2014/07/14/richard-tol-dons-cloak-climate-denial

Committee on Climate Change (2015). The Fifth Carbon Budget: The next step towards a low-carbon economy, November. https://www.theccc.org.uk/wp-content/uploads/2015/11/Committee-onClimate-Change-Fifth-Carbon-Budget-Report.pdf.

Committee on Climate Change (2016). Meeting Carbon Budgets - Implications of Brexit for UK climate policy, October. https://www.theccc.org.uk/wp-content/uploads/2016/10/Meeting-CarbonBudgets-Implications-of-Brexit-for-UK-climate-policy-Committee-on-Climate-Change-October2016.pdf.

Davies, W. (2016), The Age of Post-Truth Politics, The New York Times, 24 August 2016.

Dechezlepretre, A., Martin, R. and Mohnen, M. (2013), Knowledge spillovers from clean and dirty technologies, Grantham Institute Working Paper.

Department for Business, Energy \& Industrial Strategy (2016), $£ 4$ million boost to help businesses switch vans and trucks to electric, 23 October. https://www.gov.uk/government/news/4-millionboost-to-help-businesses-switch-vans-and-trucks-to-electric.

European Commission (2014), A policy framework for climate and energy in the period from 20202030. Communication from the Commission, Brussels (2014) (COM(2014)15). http://eurlex.europa.eu/legal-content/EN/ALL/?uri=CELEX:52014DC0015.

European Commission (2016), $\mathrm{CO}_{2}$ time series 1990-2014 per region/country http://edgar.jrc.ec.europa.eu/overview.php?v=CO2ts1990-2014\&sort=des9.

Eurostat (2016), Greenhouse gas emissions statistics, http://ec.europa.eu/eurostat/statisticsexplained/index.php/Greenhouse gas emission statistics.

Fankhauser, S., Hepburn, C. and Park, J. (2010), Combining Multiple Policy Instruments: How Not to Do It, Climate Change Economics 01 (03), pp. 209-25

Froggatt, A. Raines, T. and Tomlinson, S. (2016), UK Unplugged? The Impacts of Brexit on Energy and Climate Policy, Chatham House Research Paper, May.

FTI Consulting (2016), Brexit's Impact on R\&D Funding, 16 September 2016.

Heffer, S. (2016), Theresa May is following Enoch Powell - by actually listening to what British people want, The Daily Telegraph, 8 October 2016, available online:

http://www.telegraph.co.uk/news/2016/10/07/theresa-may-is-following-enoch-powell--by-actuallylistening-to/

Helm, D. (2015), The Carbon Crunch: How We're Getting Climate Change Wrong - And How to Fix it, Yale University Press. 
Hepburn C., Pless J. and Teytelboym A. (2016), Response to the House of Lords Economic Affairs Committee Inquiry into the Economics of UK Energy Policy: A Focus on Electricity, September 2016.

Hepburn, C., Neuhoff, K., Acworth, W., Burtraw, D., \& Jotzo, F. (2016). The economics of the EU ETS market stability reserve, Journal of Environmental Economics and Management, 80, 1-5.

Hepburn, C. and Teytelboym, A. (forthcoming), Reforming the EU ETS - Where are we now? in Parry, I., Pittel, K. and Vollebergh, H. (eds) Energy Tax and Regulatory Policy in Europe: Reform Priorities, MIT Press.

House of Commons Energy and Climate Change Committee (2016), The energy revolution and future challenges for UK energy and climate change policy: Third Report of Session 2016-17, 15 October 2016.

House of Commons Library (2016), Legislating for Brexit: the Great Repeal Bill, 21 November 2016.

Johnston, I. (2016), Climate change subsidy slashed by Government days after Brexit vote, The Independent, 4 August 2016.

Mance, H. (2016), Britain has had enough of experts, says Gove, Financial Times, 3 June 2016, available online: https://www.ft.com/content/3be49734-29cb-11e6-83e4-abc22d5d108c (accessed on 8 December 2016)

May. T. (2008), Friends of the Earth praise Theresa for her work on climate change, 1 December 2008, press release, available online: https://web.archive.org/web/20130103050332/http://www.tmay.co.uk/news/101/friends-of-theearth-praise-theresa-for-her-work-on-climate-change.

MacDonald, S. (2016). The impact of Brexit on the UK's reputation, influence and soft power. Cultural Trends, 25(4), 280-286.

Mealy P. and A. Teytelboym (2016), The Economic Complexity of the Green Economy, INET Working Paper.

Parry, I., Veung, C., \& Heine, D. (2015). How Much Carbon Pricing Is In Countries' own Interests? The Critical Role Of Co-Benefits, Climate Change Economics, 6(04), 1550019.

Randerson, J. (2010). Cameron: I want coalition to be the 'greenest government ever', Guardian, 14 May 2010, available online: https://www.theguardian.com/environment/2010/may/14/cameronwants-greenest-government-ever.

Ruddick, G. (2016). Business secretary says electric vehicles at heart of industrial strategy, Guardian, 25 November 2016, available online: https://www.theguardian.com/business/2016/nov/25/electricvehicles-greg-clark-jaguar-land-rover.

Stern, N. H., Peters, S., Bakhshi, V., Bowen, A., Cameron, C., Catovsky, S., Crane, D., Cruickshank, S., Dietz, S., Edmonson, N. and Garbett, S. L. (2006). Stern Review: The economics of climate change (Vol. 30). Cambridge: Cambridge University Press.

Stott, P. A., Stone, D. A., \& Allen, M. R. (2004). Human contribution to the European heatwave of 2003. Nature, 432(7017), 610-614.

The Economist (2016), Where Brexit and climate-change scepticism converge, The Economist (Buttonwood's Notebook), 22 May 2016 
Timothy, N. (2016), Port Talbot, globalisation - and the governing class that gains from mass immigration while poorer people lose out, Conservative Home, 5 April 2016, available online: http://www.conservativehome.com/thecolumnists/2016/04/nick-timothy-port-talbot-should-makeus-question-the-unthinking-liberalism-of-our-governing-classes.html

Tyndall, J. (1872). Contributions to molecular physics in the domain of radiant heat.

Vaughan, A. (2016), Brexit voters almost twice as likely to disbelieve in manmade climate change, Guardian, 16 June 2016.

Wong, E. (2016), Trump Has Called Climate Change a Chinese Hoax. Beijing Says It Is Anything But, The New York Times, 18 November 2016. 